\title{
Glacial Geology of the
}

Mystic Lakes-Fresh Pond Area

\section{Massachusetts}

By NEWTON E. CHUTE

CONTRIBUTIONS TO GENERAL GEOLOGY

GEOLOGICAL SURVEY BULLETIN $1061-\mathrm{F}$

Describes in particular the buried valley between Wilmington and the Charles River. Prepared in cooperation with the Department of Public Works of the Commonwealth of Massachusetts

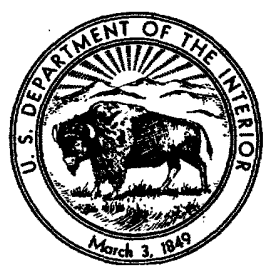




\title{
UNITED STATES DEPARTMENT OF THE INTERIOR
}

\author{
FRED A. SEATON, Secretary
}

\section{GEOLOGICAL SURVEY}

Thomas B. Nolan, Director

The U. S. Geological Survey Library has cataloged this publication as follows:

\section{Chute, Newton Earl, 1907-}

Glacial geology of the Mystic Lakes-Fresh Pond area, Massachusetts. Washington, U. S. Govt. Print. Off., 1959.

iii, 187-216 p. col. map, diagrs. $25 \mathrm{~cm}$. (U. S. Geological Survey. Bulletin 1061-F. Contributions to general geology)

Map and 3 diagrs. in pocket.

Prepared in cooperation with the Dept. of Public Works of the Commonwealth of Massachusetts.

Bibliography : p. 213.

1. Glacial epoch. 2. Geology-Massachusetts-Mystic Lakes-Fresh Pond area. I. Massachusetts. Dept. of Public Works. II. Title. IIr. Title: Mystic Lakes-Fresh Pond area, Massachusetts. (Series: U. S. Geological Survey. Bulletin 1061-F. Series: U. S. Geological Survey. Contributions to general geology)

$$
551.792
$$





\title{
CONTRIBUTIONS TO GENERAL GEOLOGY
}

\section{GLACIAL GEOLOGY OF THE MYSTIC LAKES-FRESH POND AREA, MASSACHUSETTS}

\author{
By Newton E. Chute
}

\begin{abstract}
A study of the ground-water conditions in the vicinity of Fresh Pond Reservoir in Cambridge, Mass., involves also a study of a deep sediment-filled bedrock valley that extends from the town of Wilmington southeastward to Boston Harbor. Seismic traverse records and borehole logs give accurate subsurface information.

The Fresh Pond buried valley has been traced southward from the southern part of Wilmington; it underlies Mishawum Lake, the Aberjona River, the Mystic Lakes, Spy Pond, and Fresh Pond. About a mile southeast of Fresh Pond it unites with the buried valley of the Charles River which extends seaward under the northern parts of Brighton and Brookline to Old Harbor in Boston. The Fresh Pond buried valley has an inner gorge cut about 60 to 90 feet below the floor of an older, broader valley; a rock terrace at a depth of about 80 feet below sea level is a remnant of the floor of this older valley.

The glacial deposits exposed at the surface were deposited by the last ice sheet to cover the area; deposits of older ice sheets may exist, particularly in the buried valleys, but have not been recognized. A thin discontinuous layer of till covers the highlands bordering the buried valleys, and stratified deposits formed in a sequence predominate in the valleys. The sequence began by the deposition of kames over and around remnants of glacial ice. These were followed by the deposition of clay with some interbedded sand and gravel in a body of water that covered the lowland south of the Mystic Lakes. Deposition of this clay in the Fresh Pond area ceased when the ice readvanced and scraped up part of the clay to form the Fresh Pond moraine. Thrust faults in overridden sand and gravel indicate that the direction of movement of the ice was about $\mathrm{S} .30^{\circ} \mathrm{E}$.

During and immediately after deposition of the moraine, more outwash sand and gravel were deposited. The northern borders of the outwash deposits mark the position of the ice front when deposition ceased. Deposition of outwash continued until most of the ice had melted from the valley of the Aberjona River, but ended while ice blocks still remained.

Clay with some interbedded sand and gravel was then deposited in a lake or marine embayment that spread over the lowland between the Fresh Pond moraine and the Mystic Lakes as the glacial ice melted. The surface of the water body probably stood about 25 to 30 feet above the present sea level. It is not known whether the clays of the Boston basin area, including those in the vicinity of Fresh Pond, are of marine or nonmarine origin.
\end{abstract}


After the depasition of the clay, outwash was deposited as a large alluvial fan southward over the clay. The fanlike shape and the absence of clay on the surface of the last outwash indicate that the water body in which the clay was laid down was partly or wholly drained during or before the deposition of the fan. The fan, howerer, is a part of the glacial sequence, for the hole now occupied by Spy Pond was then occupied by an ice block.

With the cessation of glacial deposition, late-glacial streams eroded the valleys in which the present streams flow. Apparently at the time of this erosion, ice blocks occupied the Mystic Lakes depressions; otherwise these basins would have been filled with sand and gravel. Since the last of the glacial-ice masses in the Fresh Pond area melted, some clay, silt, sand, gravel, and peat have been deposited in the streams, ponds, and marshes.

The relations of the various glacial deposits give a clue to the movement of ground water. Clay and clayey till are too impermeable to permit much movement of ground water; there is little flow, therefore, from the clayey areas into Fresh Pond. The sand and gravel on the northwest side of Fresh Pond seem to provide the pond with the greatest amount of ground water. If there is any important southward movement of ground water within 60 feet of the surface along the buried valley to Fresh Pond, it is probably through thick peat deposits and associated sands.

\section{INTRODUCTION}

A study of the ground-water conditions in the vicinity of Fresh Pond Reservoir in Cambridge, Mass., and in adjacent areas where important supplies of ground water might be found, was made by the Water Resources and Geologic Divisions of the United States Geological Survey. The investigation was part of a cooperative geologic program with the Massachusetts Department of Public Works and was requested by $A$. D. Weston, chief engineer of the Massachusetts State Department of Health.

W. O. Crosby (1899, p. 302) suggested the probable existence under Fresh Pond of a deep bedrock valley filled with glacial and postglacial sediments. He thought that this valley had been eroded by the preglacial Merrimack River and therefore extended from the present Merrimack River near Lowell, which is about 8 miles northwest of Wilmington, southeastward to Boston Harbor. Subsequent work by I. B. Crosby (1939, p. 376) and the Geological Survey has confirmed the existence of the valley south of Wilmington, but the recently acquired data strongly suggest that it does not extend to the Lowell area, and therefore is not part of the preglacial Merrimack River system.

Because of the possible importance of the sediments in this valley as sources of ground water, a large part of the valley area was included in the ground-water study. During the spring and fall of 1944, the Geologic Division mapped the surface geology and studied the geology of the deposits that fill the valley and its tributaries between Wilmington and the Charles River in Cambridge and Watertown. Borehole logs collected by M. L. Brashears, Jr., C. M. Roberts, 
and H. S. Taylor, of the Water Resources Division of the U. S. Geological Survey, were used in the preparation of the report.

The results of seismic traverses made in 1944 by the Rev. D. J. Linehan, S. J., and E. T. Apfel have been included in the report. These traverses were made to locate the valley in places where it could not be traced at the surface and to determine the depths to bedrock.

\section{ACKNOWLEDGMENTS}

The writer was assisted in the fieldwork by J. P. Schafer. A. D. Weston, of the Massachusetts Department of Public Health, provided pertinent maps and reports; the Metropolitan Sewer Commission, sewer excavation and boring records; and the municipal engineers of Cambridge, Watertown, Belmont, Arlington, and Winchester, information concerning the subsurface geology of their respective towns.

\section{BURIED VALLEY}

\section{ORIGIN}

Several buried stream-carved bedrock valleys of southern New England, including the valley that underlies Fresh Pond and the Mystic Lakes, have floors as much as 200 feet or more below mean sea level, near the present seacoast. The location of some of these valleys in Massachusetts has been shown by I. B. Crosby (1939, p. 375). As stream erosion does not take place more than a few feet below sea level, and as glacial erosion probably did not deepen the valleys greatly except in a few places, New England must have stood higher relative to sea level when these valleys were formed than it does at present. These buried valleys formed before the last glaciation of the region; they are now partly or completely filled with unconsolidated sediments mainly of glacial origin.

The buried valleys show evidence of at least one important uplift of the land or lowering of sea level during their formation. As pointed out by I. B. Crosby $(1945$, p. 393$)$ this is indicated by the presence in each of an inner gorge cut into the floor of an older, broader valley. Borings on the north side of Fresh Pond in Cambridge show that the buried valley has an inner gorge that was cut 60 to 90 feet below the valley floor; the rock terrace at about 80 feet below mean sea level is a remnant of the floor of this older valley (pl. 15, east-west section).

\section{LOCATION}

The buried valley-designated in this report as the Fresh Pond buried valley-has been traced southward from the southern part of Wilmington; it is known to underlie Mishawum Lake, the Aber- 
jona River, the Mystic Lakes, Spy Pond, and Fresh Pond. About a mile southeast of Fresh Pond it unites with the buried valley of the Charles River (pl. 14) which extends seaward under the northern parts of Brighton and Brookline to Old Harbor in Boston.

The part of the buried valley north of Lower Mystic Lake is in the Fells Upland where, because of the relatively high relief, it is only partly filled; it can be traced roughly by the topography and the outcrops of bedrock. In the Boston lowland south of Lower Mystic Lake, this valley and the buried valleys of the preglacial Charles and Neponset Rivers are so deeply buried that they are traceable only by subsurface exploratory methods, such as borings and geophysical traverses.

That the Fresh Pond buried valley was not formed by the preglacial Merrimack River as W. O. Crosby suggested (1899, p. 302) is indicated by the narrowness of the valley in the southern part of Wilmington. More subsurface studies must be made, however, before the extent of the buried valley north of the Woburn-Wilmington town line can be known.

LaForge, who also believes that this buried valley was not a part of the preglacial Merrimack River valley, wrote (1932, p. 79) :

A deeply buried valley extends southward from Winchester through the Mystic Lakes, across eastern Arlington and western Cambridge, thence between Brighton and Cambridgeport, and across eastern Roxbury and Dorchester Neck to the Old Harbor, and there is little doubt that it is the valley of the Pliocene predecessor of the Mystic River. On account of its considerable depth, more than 200 feet in Dorchester, some have assumed that it could not have been made by a stream with so small a drainage basin as the present Mystic and have asserted that it is the valley of the Pliocene Merrimack. The author knows of no facts in support of this conclusion. Evidence is lacking of a buried valley extending through to the present source of the Merrimack, and such a valley, if it ever existed, must have crossed the present valley of the Shawsheen River, which apparently is also a preglacial valley.

I. B. Crosby $(1939$, p. 376) summarized his views concerning the location and extent of the buried valley as follows:

A broad valley continues through the hills of Woburn, and wells in North Woburn, East Woburn and Winchester show that there is a deeply buried valley. It has not yet been proved whether the preglacial Merrimack valley continued through the hills and was continuous with the buried valley in Woburn or whether there was a low divide near the Woburn-Wilmington line. If the preglacial Merrimack did not go this way, it probably flowed easterly from Wilmington towards Salem. In any case, we know that there is a continuous valley, now filled with glacial deposits, extending down through Woburn, Winchester, Arlington, Cambridge, Allston, and the South End to Dorchester Bay.

\section{DESCRIPTION}

The buried valley increases in width and depth southward from Wilmington. The narrowest part known south of Wilmington is a 
mile northwest of the north end of Mishawum Lake where outcrops of bedrock on either side of the buried valley are only about 900 feet apart. Wells are said to have been drilled here to a depth of 80 feet without reaching bedrock. At the south end of Mishawum Lake, the Consolidated Chemical Industries Co. has 5 wells in the buried valley; 2 of these wells are 50 feet deep and 3 are 85 feet deep, but none of them reach bedrock. Well 4, located 100 feet north of the south end of the lake and on the west side, has the following log, as reported by the driller:

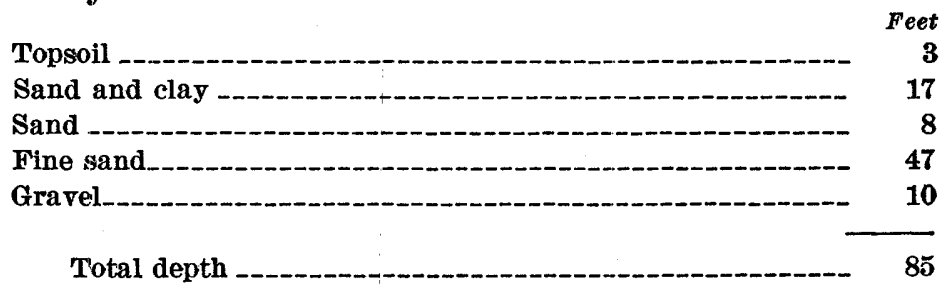

From Mishawum Lake southward to the Mystic Lakes the buried valley coincides with the course of the Aberjona River. According to I. B. Crosby (1937, p. 221), a well at the north end of Aberjona Pond in Winchester was drilled to a depth of 145 feet without reaching bedrosk. The upper part of the buried valley is narrow and clearly defined at Wedge Pond and at the Mystic Lakes where outcrops show its width as about 2,500 feet. Between Wedge Pond and the Mystic Lakes the surface valley widens, but the presence of an outcrop along the Boston and Maine Railroad right-of-way indicates that there the buried valley is to the west of the tracks. Along the seismic traverse between the Upper and Lower Mystic Lakes (fig. 33, section A-C), the bottom of the buried valley is about 165 feet below mean sea level, or 175 to 180 feet below the surface.

In the lowland south of the Mystic Lakes the buried valley is cut in the sedimentary bedrock of the Boston basin. As these rocks are less resistant to erosion than the igneous and metamorphic rocks in the area to the north, the buried valley is wider in the basin than elsewhere. Between the Lower Mystic Lake and Fresh Pond the buried valley is 1 to 2 miles wide. Borings show that along the north side of Fresh Pond it is about 2 miles wide and has an inner valley about 4,000 feet wide. The deepest part of this inner valley penetrated by the borings is 170 feet below mean sea level, whereas the buried rock terrace on the east side of the inner valley is only about 80 feet below mean sea level. (See pl. 15.)

A seismic traverse of the bedrock surface was run along the railroad from Alewife Brook to the east side of Spy Pond (pl. 14, fig. 33, section $\mathrm{D}-\mathbf{J}$ ). The bedrock surface is from about 130 to 170 feet below mean sea level between Alewife Brook and point $F$ on the east side of Spy Pond. A corresponding depth to bedrock is shown by 
Letters $A$ to $P$ mark shot points For location of sections, see plate 14

. $500 \quad 10,00 \quad 1500$ Feet

Depths to bedrock determined by seismo. graph by D. J. Linehan, seismologist, and E. T. Apfel, geologist, 1944

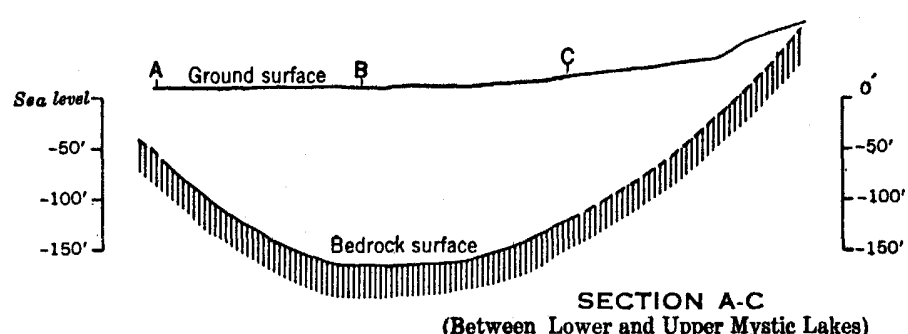

(Between Lower and Upper Mystic Lakes)
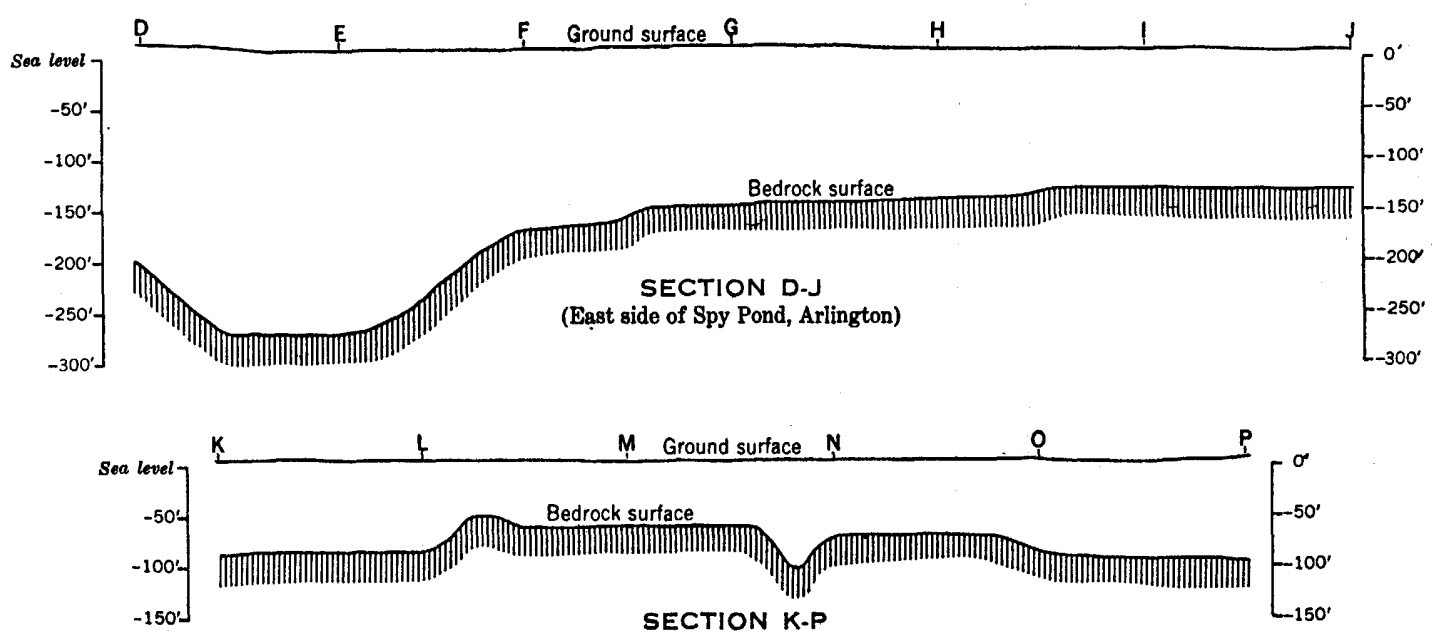

(North side of Charles River, Cambridge)

FrgurE 33.-Profile sections of the bedrock surface in the buried valleys that underlie the Mystic Lakes and the Charles River. 
borehole 174 (pl. 15), which is about 200 feet southwest of point $H$, and ends on bedrock at a depth of 169 feet below mean sea level. The seismic data indicate that near point $\mathrm{E}$ the bedrock surface is about 270 feet below mean sea level. This is 100 feet deeper than the maximum depth of the buried valley on the north side of Fresh Pond. The cause of this much greater depth is not known, but it may be due to unusually deep local glacial erosion.

Southeast of Alewife Brook, the east side of the buried valley appears to coincide with Massachusetts Avenue. Bedrock was found within 8 feet of the surface in a sewer ditch on the northeast side of Massachusetts Avenue between Davenport and Beech Streets (just off the mapped area), a short distance northwest of the Cambridge railroad station. A ditch 10 to 15 feet deep, on the southwest side of Massachusetts Avenue in the same locality, did not reach bedrock, a fact which suggests that the bedrock surface slopes in that general direction. Several other borings a short distance to the east and southeast reached bedrock at depths ranging from 8 to 48 feet below mean sea level.

For the area between Fresh Pond and the Charles River very few deep-boring records are available. Borehole 119 (pl. 14) at the corner of Merrifield and Arlington Streets, Watertown, struck bedrock at $51 / 2$ feet below mean sea level, or $401 / 2$ feet below the surface. Borehole 116 on the east side of Arlington Street and about 1,500 feet north of the Charles River, reached bedrock at 22 feet below mean sea level. Borehole 47 located 1,500 feet west of hole 116, where the surface is 27 feet above sea level, reached bedrock at 9 feet below mean sea level. Borehole 109, on the north side of the Charles River and just east of the Watertown Arsenal, reached bedrock 69 feet below mean sea level; this hole is probably on the north side of the buried valley of the Charles River. Borehole 117, located 1,000 feet northeast of hole 109, ends 58 feet below sea level without reaching bedrock. Borehole 112, on the north side of Arsenal Street between holes 109 and 47, entered bedrock near mean sea level, but hole 50, at the Watertown Arsenal and only about 800 feet south of borehole 112, did not reach bedrock at a depth of 68 feet below mean sea level; this hole also is probably in the buried valley of the Charles River. These boreholes indicate that a buried valley underlies the Charles River in this locality and that bedrock is close to the surface in the area west of Mount Auburn Cemetery and north of the Watertown Arsenal.

The seismic traverses along the north side of the Charles River, section K-P (fig. 33), show that, along the line of the traverses, the bedrock surface is from 50 to 100 feet below mean sea level. These traverses are on the north side of the buried valley of the Charles River, and, as the bedrock surface along the section is nowhere deeper than 100 feet, the deeper part of the Fresh Pond buried valley must 
join the buried valley of the Charles River to the east of the line of traverses as indicated on plate 14. The borehole data described above prove that the Fresh Pond buried valley is not west of the seismic traverse.

\section{TRIBUTARIFS}

The Fresh Pond buried valley was formed by river erosion, and like other river valleys it has tributaries. The surface topography and geology indicate that a tributary buried valley may underlie the stream that flows into the north end of Mishawum Lake from the northeast; others may underlie Horn Pond and Horn Pond Brook in Woburn and Winchester, Mill Brook in Arlington, the Mystic River in Medford, and the valley between Belmont and Waltham.

The buried tributary valley that is thought to underlie the stream that flows into the north end of Mishawum Lake may follow the course of the present stream to the north end of Mishawum Lake, or it may turn south 2,000 feet east of the lake and pass under the eastern arm of the lake. Outcrops on the northwest side of the surface valley and bedrock at a shallow depth in well 51 (pl. 14) show that half a mile northeast of Mishawum Lake the buried valley is between 600 and 700 feet wide at the level of the floor of the present surface valley.

Little is known concerning the depth or length of the buried tributary valley that is thought to underlie the valley that now contains Horn Pond and Horn Pond Brook. The outcrop in the center of the present surface valley, 2,000 feet north of the north end of Horn Pond, indicates that there the buried valley is probably not more than 800 feet wide. South and southeast of Horn Pond, the valley is indicated by a well, a few hundred feet south of the pond near Horn Pond Brook, which penetrated gravel to a depth of 45 feet without reaching bedrock.

The buried tributary valley of Mill Brook joins the main buried valley near the south end of the Lower Mystic Lake. This tributary is very short and borings show that it does not extend farther northwest than Brattle Street, which crosses the valley near the Brattle railroad station, about three-quarters of a mile upstream from the mouth of the present Mill Brook valley. From Brattle Street northwest to the Arlington Reservoir at the Arlington-Lexington town line, borings show that bedrock is only from 3 to 10 feet below the bottom of the present valley.

The present valley of the Mystic River east of the Lexington quadrangle was not studied for this report, but on his map of buried valleys I. B. Crosby (1939, p. 375) shows a north-south bedrock divide under the present Mystic River at Medford Square in the Boston North quadrangle. If this bedrock divide is correct, there can be only a short buried tributary valley west of the divide. 
The present valley, which serves as a route for the Boston and Maine Railroad west of Fresh Pond, is probably underlain by a buried valley, but its depth and extent are not known. According to the city engineer of Belmont, piles were driven along a sewer excavation in the valley to depths of 30 to 35 feet below the surface without striking bedrock. Crosby (1939, map, p. 375) shows a buried bedrock divide crossing this valley a short distance south of the Belmont town hall where a hill nearly closes the surface valley. This hill, which is probably composed of till, is not an indication of the presence of a bedrock divide. Clapp (1902, p. 226) considered this valley a possible course of the buried valley of the preglacial Charles River, but such a hypothesis seems doubtful.

\section{GLACIAL GEOLOGY}

\section{CHRONOLOGY OF EVENTS}

The surface geology and the logs of boreholes show that the buried valley between Wilmington and the Charles River is filled with interbedded till, gravel, sand, silt, clay, and peat. The history of these deposits (pl. 14) is complicated and difficult to ascertain, but the 10 principal incidents in their formation, here referred to as events, are listed in chronological order as follows:

Advance of the ice and deposition of ground moraine.

Retreat of the ice front and deposition of outwash 1.

Deposition of clay with some interbedded sand and gravel (not exposed) in ponded water or a marine embayment.

Readvance of the ice to form the Fresh Pond moraine and the deposition of outwash 2.

Retreat of ice front and deposition of outwash 3.

Deposition of clay with some interbedded sand and gravel in ponded water or a marine embayment.

Deposition of outwash 4.

Erosion of valleys in the outwash; now occupied by the Aberjona River, Mill Brook, Horn Pond Brook, Alewife Brook, and the Mystic River.

Melting of separated ice blocks that occupied the present pasitions of Fresh Pond, Little Pond, Spy Pond, the Mystic Lakes, Wedge Pond, and Winter Pond.

Formation of peat and the deposition of postglacial sand, silt, and clay in the lowest areas.

The glacial deposits of this sequence of events were formed by the last ice sheet that covered the area. Deposits made by older ice sheets are not known, though some may be present under the younger deposits, particularly in the lower parts of the buried valleys.

\section{FIRST: DHPOSITION OF GROUND MORAINE}

Till deposited by the last ice sheet covers the highlands bordering the buried valley. This till sheet has not been identified with certainty in the logs of the boreholes in the buried valley. Some of the 
deposits shown on plate 15 as gravel, sand, and clay may be composed in part of till, but from the distribution of these deposits, as indicated by borings, it is almost certain that some of them are water laid. A fairly continuous sheet of till probably was deposited by the ice at this time; how much of it remains in any area depends upon the amount of subsequent glacial and stream erosion. The till is shown diagrammatically in the sections on plate 16 , though very little is known of its distribution, depth, and thickness in the buried valley.

\section{SECOND: DEPOSITION OF OUTWASH 1}

Outwash 1 is represented by the kames in and east and west of Mount Auburn Cemetery. Kames are knobby hills composed of sand and gravel. They are of diverse origin but commonly are deposited by glacial melt water against the margins of glacial ice or in depressions in the marginal zones of the ice. The largest kame in the area is near the center of Mount Auburn Cemetery and is about 100 feet high.

While the sands and gravels of the kame area were being deposited remnants of the glacial ice lay scattered over the area, particularly in the northern half of the Mount Auburn Cemetery. The sands and gravels were deposited over and around these ice blocks, which on melting left holes or depressions known as kettles in the deposits.

The kames differ considerably in composition. On both sides of Grove Street west of Mount Auburn Cemetery, they contain many boulders and in places the gravels are so poorly sorted as to resemble till. Cuts in the prominent kame between Arlington and Grove Streets expose sand with some pebble-sized gravel on the south side of the kame and pebble- and cobble-sized gravel on the east side. Where not obscured by slumped material, the kames show good bedding with the layers inclined southward at various angles. Because the kames are a considerable distance south of the Fresh Pond moraine and thus beyond the probable maximum extent of the local ice lobe that readvanced to form the moraine, they probably were deposited before the readvance. For this reason the kames are considered as slightly older than the Fresh Pond moraine.

In section $S-S^{\prime}$ (pl. 16), the kames are shown as resting on a bedrock ridge that separates the buried valley of the Charles River basin from the buried valley that underlies Fresh Pond. The depth to bedrock in the Mount Auburn and Cambridge Cemeteries is not known, but the presence of the bedrock ridge is indicated by the shallow depths to bedrock in borings made on the west side of the Mount Auburn Cemetery.

THIRD: DEPOSITION OF CLAY

As the ice melted from the Boston lowland, clay with some interbedded sand and gravel was deposited in a body of water that covered 
the lowland south of the Mystic Lakes. The deposition of the clay ended in the Fresh Pond area when the ice readvanced and scraped up part of the clay to form the Fresh Pond moraine (fourth event). The clay in the moraine resembles the younger clay (sixth event) now exposed in the clay pits north of the moraine. Both clays were probably formed under similar conditions.

The formation and existence of the clay of the third event are inferred from the clayey character of the Fresh Pond moraine. Some of the clay and its associated sand and gravel must have escaped erosion by the ice. However, as no significant differences between the clay of this time and that of the sixth event are known, it has not been possible to distinguish between them in the logs of the boreholes. The geologic cross sections shown on plate 16 imply that some of this older clay is preserved in the lower part of the buried valley in the Fresh Pond area.

The clay that underlies the outwash plain on the south side of the Fresh Pond moraine is believed by the writer to have been deposited at this time. If this correlation is correct, the altitude of the surface of this part of the clay deposit probably is equivalent to the original surface altitude of the part that was eroded to form the Fresh Pond moraine. The covering of outwash sand and gravel prevented the deposition of any of the younger clay south of the moraine and also preserved the clay surface from postglacial stream erosion. Five boreholes on the north side of Mount Auburn Street, between Willard and Bradbury Streets, penetrated blue clay underlying peat, silt, sand, and gravel at depths ranging from 33 to 37 feet below the surface, or from about 18 to 22 feet below mean sea level. It is probable, therefore, that the surface of the clay in the area north of the moraine was about 20 feet below present mean sea level when the ice readvanced to form the Fresh Pond moraine.

The clay of the third event is believed to be preserved in the buried valley somewhat as indicated in the sections because of the limitations imposed by the size of the Fresh Pond moraine on the amount of clay that could have been eroded by the ice. If the surface of this clay deposit was about 20 feet below present mean sea level at the time the ice readvanced, it is unlikely that the ice could have eroded to the bottom of the buried valley without forming a much larger moraine. Some of the eroded clay undoubtedly was carried away by melt water, but probably only a small amount was removed in this manner.

\section{FOURTH: FORMATION OF THE FRESH POND MORAINE AND OUTWASH 2}

The Fresh Pond moraine seems best explained as having been formed by a short readvance of the ice during the general retreat of the last ice sheet to cover this region. As the ice readvanced probably as a 
local small lobe or tongue, it apparently scraped up part of the clay previously deposited in the lowland north of the moraine and shoved it into place in the present ridge. Workers who have considered the ridge to be a moraine include Woodworth $(1897$, p. 101), Lane (1928, p. 10), I. B. Crosby (1934, p. 149), and LaForge (1932, pl. 2).

Most of the moraine is in a residential area of Cambridge where there is little opportunity to observe the materials in it. The best exposures are along the shores of Fresh Pond and behind the houses on the east side of Aberdeen Avenue south of Fresh Pond. On Arlington Street, near its junction with Washington Street, a ditch about 8 feet deep exposed silty clay that contained scattered stones about 1 inch across. No stratification was observed in the clay. A similar clayey material was seen in a ditch 2 to 3 feet deep in the backyard of Prof. Kirk Bryan's residence on Washington Street, which is near the end of Arlington Street in the Boston North quadrangle, just beyond the east edge of the mapped area. A small boulder was observed in this ditch; Bryan told the writer that he had found other boulders and also wind-cut cobbles and pebbles on his property.

The till in all of these exposures of the Fresh Pond moraine is very clayey and contains scattered pebbles and a few cobbles and boulders. Some sand and gravel are probably mixed with the clay. The part of the moraine which projects as a point into the southeast side of Fresh Pond has sand and gravel exposed at its northwest end. It was not determined, however, whether the sand and gravel were deposited with the clay or after the moraine had been formed. Sand and gravel are also exposed in the cliff at the west end of the moraine at the south side of Fresh Pond; this sand and gravel is probably part of outwash 2 which was deposited in the space between the moraine and the ice block that occupied Fresh Pond.

The clayey till of the Fresh Pond moraine differs greatly in composition from the typical sandy till deposited by the latest ice elsewhere. As stated, the character of the Fresh Pond moraine is clayey because it was formed mainly of material scraped up by the ice from the lowland north of the moraine. Woodworth (1897, p. 101) held this opinion, for he stated that the moraine is "a complex structure of glacial materials" with a core of clay pushed up from the area on the north when the ice readvanced slightly "on the line of the Woburn-Arlington depression, causing the ice to excavate the underlying clays in Belmont and Cambridge."

Prof. Bryan told the writer that he observed varved clays on the crest of the moraine in house basement excavations west of Washington Street, Cambridge. These may be local deposits formed in temporary ponds on the moraine.

Lane (1928, p. 8-11) observed 5 to 7 feet of the till at the east end of the Fresh Pond moraine resting on horizontally bedded sand and 
gravel in an excavation at the northwest corner of Arlington Street and Massachusetts Avenue, Cambridge. The ice overrode the sand and gravel when the moraine was formed and developed several thrust faults in them. According to Lane the thrust faults dip N. $30^{\circ}$ W., which is perpendicular to the main body of the moraine in this locality, and indicates that the direction of movement of the ice was about S. $30^{\circ}$ E. An excellent photograph showing the till resting on the faulted sand and gravel is included in his paper.

One of the characteristic features of the Fresh Pond moraine is its lack of continuity. It has not been traced east of Massachusetts Avenue in Cambridge; the west end of the main body of the moraine is at the south side of Fresh Pond. Two isolated hills of till northwest of Fresh Pond have been tentatively labeled by the writer as parts of the Fresh Pond moraine, which would extend the moraine, by interpretation, interruptedly to the edge of the Boston basin near the Belmont town hall. One of these hills is about 2,000 feet northwest of Fresh Pond, just south of Concord Avenue. It is considered part of the moraine because the till on the northeast side of the hill, where there has been some excavation, is clayey and resembles the main part of the Fresh Pond moraine. However, the till in the narrow area shown on the map as extending north from this hill is stony.

The other hill is between Goden and Pleasant Streets, south of Concord Avenue, Belmont. Clayey till was found on the northeast side of this hill at the corner of Common and Waverley Streets and also in the playground west of Cottage Street. The character of the till could not be determined over the entire hill because of the residential development. The northeast corner and the west side of the hill are covered by sand which is probably wind deposited. As this part of the moraine is near the north edge of the basin in which the clay is assumed to have accumulated, it probably contains a smaller proportion of the clayey till than the main part of the moraine near Fresh Pond.

As the moraine overlies the buried valley and is not known to extend beyond, it is reasonable to assume that it was formed from unconsolidated deposits contained within the valley to the north of the moraine. At the time of the readvance of the ice the part of the buried valley near Fresh Pond probably was filled, as it is now, with thick, easily eroded sediments that were scraped up in large quantities and deposited at the margin of the ice to form the moraine. The unconsolidated deposits overlying the bedrock were thin on both sides of the buried valley, so that the ice eroded comparatively little material and little or no moraine was formed.

A readvance of the ice, possibly the same as that which formed the Fresh Pond moraine, may be indicated by the till layer reported by 
W. O. Crosby $(1903$, p. 83-84) as occurring in the clay in the northern part of Boston. He says:

In a number of the East Boston tunnel borings, on the west side of the harbor, and more or less in the lee of the Copps Hill drumlin, the clay is divided, usually near the bottom, by a sheet of boulder clay from 10 to 25 feet in thickness. Similar phenomena have been observed elsewhere, as in the lee of the Beacon Hill drumlin and as previously noted, in one of the Charlestown Bridge borings. Apparently this means that when the deposition of the clay began in this part of the harbor the margin of the ice sheet was still near by, so that a slight readvance of the ice spread a layer of boulder clay over a part of the blue clay.

He goes on to say, however, that he thinks it more probable that the till was deposited by floating ice.

The horizontally bedded clay exposed in the large pit of the New England Brick Co., on the northeast side of Fresh Pond, rests on stony till with a sharply defined contact at a depth of about 50 feet. The till is clayey and is full of glacially striated fragments of Cambridge slate. The writer believes that this till was deposited during the readvance of the ice at the time the Fresh Pond moraine was formed.

The sand and gravel that compose outwash 2 were deposited on the south side of the moraine and west and northwest of Fresh Pond during and immediately after the formation of the Fresh Pond moraine. At the time of the deposition of these sands and gravels most of the area north of the moraine was covered by ice. The northern borders of the outwash deposits of this event mark the position of the ice front when deposition ceased.

The gravel ridge on the north side of Fresh Pond, from the Cambridge Sanatorium to and including the grounds of the City Home, must have been deposited in a narrow re-entrant in the ice. The head of the outwash plain is just north of Concord Avenue where the surface declines to the marshy lowland that is now largely covered with fill. That this outwash plain was formed by streams that flowed from north to south is shown by the decrease in coarseness of the gravel from north to south and the greater amount of sand in the southern part of the deposit.

A peculiarity of this outwash deposit is the presence of one or more beds of clay interbedded with the sands and gravels in the northern part of the deposit. A bed of clay, 5 to 6 feet thick, is exposed at two places on the east side of the hill on which the Cambridge Sanatorium is located. One exposure is on the slope above the end of the railroad siding at the Ryerson steel plant and the other is 150 feet farther northeast. The clay has not been traced between the two exposures because of slump, but it is probable that both exposures are of the same bed because they are at approximately the same elevation and have the same character and thickness. The clay bed on this hill is overlain by 5 to 15 feet of gravel and sand. Clay is also exposed at 
wie surface about 600 feet north-northeast of the sanatorium and in the gravel pit 400 feet farther northeast. All of these clay exposures probably belong to the same bed.

A 10-foot bed of clay that is interbedded with sand and gravel was observed by Woodworth (Shaler and others, 1896, p. 990, fig. 37) in a cut on the west side of Fresh Pond. This bed is not now exposed and its exact location is uncertain, but it also may be part of the clay bed that is exposed at the sanatorium.

Some clay was found on the west side of the old gravel pit on the south side of Concord Avenue, about 1,500 feet northwest of Fresh Pond. The exposure is poor, however, and it could not be determined whether the material is the clayey till or water-laid clay in place. The overlying stratified sand contains small irregular masses of clay that apparently were eroded from the underlying beds and deposited with the sand.

Several beds of clay, which range in thickness from a fraction of an inch to a foot or more, and which are interbedded with sand and fine gravel, were exposed in a house basement excavation 1,800 feet northwest of Fresh Pond, on the east side of Bright Road 400 feet south of its junction with Concord Avenue. The beds have been deformed and are now tilted steeply in various directions.

That the beds of clay mentioned above were deposited before the clay of the sixth event which underlies the lowlands to the north and east, is proven by the fact that the clay of the sixth event overlies and is therefore younger than sands and gravels with which these various beds of clay are interbedded. The area underlain by the younger clays of the sixth event was covered by ice while the clay that is interbedded with the sand and gravel of outwash 2 (the fourth event) was being deposited.

The clay interbedded with outwash 2 in the hill at the Cambridge Sanatorium is 15 to 20 feet above present mean sea level, that near the gravel pit on the south side of Concord Avenue is 35 to 40 feet above mean sea level, and that exposed in the excavation on Bright Road is about 70 feet above mean sea level. The clay beds of the last two localities are higher than any other clay beds observed in this area. Woodworth $(1897$, p. 101) said that the kames on the west side of Fresh Pond in this vicinity showed marked signs of having been overridden by the ice and that "heads" of clay had been squeezed up into the sand and gravel from below. Folds in the strata of the outwash observed in a former cut on the west side of Fresh Pond were cited as evidence that the outwash had been overridden. The outwash may have been disturbed locally by minor fluctuations of the ice front at the time the outwash was being deposited, but the writer found no evidence that the ice had overridden the sand and gravel deposits of outwash 2 on the west side of Fresh Pond. More- 
over, this outwash is not overlain by till, such as would be expected had it been overridden by the ice. The folds observed by Woodworth west of Fresh Pond and those observed by the writer in the basement excavation on Bright Road, might have been formed either by very slight readvances of the ice front which deformed the deposits laid down against it or by slump resulting from the melting of ice blocks bordering or buried in the outwash.

\section{FIFTH: DEPOSITION OF OUTWASH 3}

Deposition of the kames, kame terraces, and outwash plains of outwash 3 began toward the close of the period of deposition of outwash 2 and continued until most of the ice had melted from the valley of the Aberjona River. It ended before the melting of the ice blocks that formed the kettle holes now occupied by Winter Pond and Wedge Pond and while a large ice mass remained in the lowland between Fresh Pond and the Mystic Lakes. Outwash 3 extends up the Aberjona River valley to the vicinity of the Wilmington town line where it apparently forms a group of coarse gravel kames.

The outwash surface south of Winter Pond is highest near the mouth of the valley southwest of the pond, suggesting that at least some of the sand and gravel was brought in through this valley.

Kame terraces were formed at this time on both sides of the Mystic Lakes. The east terrace ends near the south end of the Lower Mystic Lake, but the west terrace extends southwest along the side of the Boston basin to the vicinity of the Belmont town hall. These terraces have uneven surfaces and frontal slopes owing to the melting of ice blocks buried in them and to subsequent stream erosion.

The kames on the south sides of Spy Pond and Little Pond also probably formed at this time in holes in the ice. They probably rest on clayey till or on the clay of the third event where the till is absent (pl. 16, section $S-S^{\prime}$ ).

Outwash 3 differs in composition from outwash 2. Northwest of Fresh Pond, outwash 3 is composed of silt, sand, and pebble-sized gravel, and outwash 2 in nearby areas is composed chiefly of pebbleand cobble-sized gravel. This difference in composition and the separation of the deposits constitute the principal reason for believing that outwash 2 and outwash 3 are not contemporaneous. The streams that formed the deposits of outwash 3 probably escaped through the gap now used as a railroad route, just southwest of the Belmont town hall, because the deposits appear to be graded toward this gap.

\section{SIXTH: DEPOSITION OF CLAY}

Clay, with some interbedded sand and gravel, was deposited in a lake or a marine embayment that spread over the lowland between the Fresh Pond moraine and the Mystic Lakes as the glacial ice 
melted. According to W. O. Crosby (1890, p. 135), the clay of the Boston basin lowland is composed to a large extent of rock flourmaterial that is ground by the glacial ice and transported to the water body by streams of melt water. The glacial origin of the clay is shown by the presence in it of scattered boulders, many of which show glacial striae. These boulders, some of which are 5 to 10 feet in diameter, must have been dropped into the clays from masses of floating ice while the clays were being deposited. Others who have studied the clays in the Boston region have noted the boulders and have also attributed them to ice rafting. Shaler, Woodworth, and Marbut (1896, p. 990) described them as follows:

Scattered through the formation are boulders ranging in size from small pebbles to masses weighing several tons. The most abundant are about the size of a man's head. These boulders usually display glacial striae and surfaces smoothed by glacial attrition. Their presence in the clays seem best explained by supposing them to have dropped from floating ice during the deposition of the beds.

The thickness of the clays of this event varies according to the configuration of the surface on which they were deposited. At the New England Brick Co. pit in Cambridge, 0.2 mile northeast of Fresh Pond, the deposit is about 50 feet thick and is underlain by a layer of till. The clay of the sixth event is underlain by an estimated 30 to 100 feet or more of older sediment, some of which probably is clay that was deposited before the ice readvanced to form the Fresh Pond moraine. Clayey till may separate the two clay deposits in many places-as is shown in the sections on plate 16-but till is not identified with certainty in the logs of the boreholes. For this reason no reliable estimates can be made of the thickness of the clay of the sixth event from these logs.

The clay is at, or within 2 or 3 feet of, the surface in the area along the north sides of the Fresh Pond moraine, Fresh Pond, and the area of outwash 2 northwest of Fresh Pond. From one-half to three-quarters of a mile north and northeast of Fresh Pond to the lower Mystic Lake the clay is overlain by the gently sloping fanlike deposit of sand and fine gravel of outwash 4 . The presence of the clay underneath the sand and gravel is shown by the borehole logs (pls. 15, 17). The northernmost borehole to show clay that probably was formed in this stage is No. 1655 , which is one-half mile east of the south end of the Lower Mystic Lake.

Various estimates of the altitude of the surface of the water body in which the clays were deposited have been made from the altitudes of the deposits. I. B. Crosby (1934, p. 148) says that "the highest known glacial clay, except small deposits that obviously formed in glacial lakes, is 30 or 40 feet above low tide." As Boston has an average tide range of about 10 feet, the height above mean sea level 
would be from 25 to 35 feet. Evidences of old shorelines in the Fresh Pond area, such as deltas, beaches, bars, and wave-cut cliffs, were sought but none were found. As the water body was only about 2 miles wide and 3 miles long, and as it was interrupted by blocks of ice which formed islands within it, wave action apparently was not strong enough to form prominent shore features; such features as were formed have been obscured by the construction of streets and houses.

In the absence of recognizable shoreline features the height to which clay is found on the slopes bordering the lowland was used in estimating the minimum altitude of the surface of the water body. Near the New England Brick Co. pit the surface of the clay is only 5 to 10 feet above mean sea level. The logs of boreholes indicate that in the lowland area between the clay pit and the Mystic Lakes the surface of the clay is generally from a few feet above to a few feet below mean sea level. The logs of boreholes 172 and 174 east and southeast of Spy Pond (pl. 15) show sand to depths of 20 and 28 feet below mean sea level, respectively. As this sand contains some interbedded clay, that part of the deposit below mean sea level may be a sandy phase of the clay deposit of the sixth event.

Clay was found about 20 feet above mean sea level on the south side of the hill at the south end of Little Pond in Belmont, about 10 to 15 feet above mean sea level southwest of Little Pond, and about 15 feet above mean sea level at the east end of the gravel ridge that borders the north side of Fresh Pond in Cambridge. The clay of the last locality is shown in borehole 796 (pls. 14, 15). As it is likely that there was enough wave action in most places to prevent the deposition of clay up to the shoreline, it is probable that the surface of the water body stood 5 to 10 feet above the highest clay deposits noted, or, as a rough estimate, between 25 and 30 feet above present mean sea level. Hörner (1929, p. 130) suggested that the highest position of the water level in this locality, which he called the marine limit, was at an altitude of 40 feet; however, he based his judgment on the altitude of the sand and gravel deposits at the south end of the Mystic Lakes which the writer believes were deposited as an alluvial fan on the clay after the level of the water body had fallen.

Had the water body been very shallow as the clay accumulated, shallow water structures, such as ripple marks or mud cracks, would be expected, but none were observed in the clay or interbedded sand layers exposed in the clay pits. At the close of this event the land must have risen sufficiently to bring the area above sea level. I. B. Crosby (1934, p. 157) says that the land rose until sea level was about 70 feet lower than at present. 
The clay was deposited rapidly because deposition had ceased before the ice blocks that occupied the basins of Fresh Pond, Little Pond, Spy Pond, and the Mystic Lakes had melted. The glacial streams that flowed into the area must have been heavily laden with clay and silt.

Good exposures of the clay were seen in 1946 on the north, west, and south sides of the large clay pit then operated by the New England Brick Co. About 50 feet of clay was exposed resting on stony till at the bottom of the pit. The clay is stratified from the bottom to within a few feet of the top where the bedding is obscured by postglacial weathering. The bedding is due to the presence of many fine sand and silt layers which range from a fraction of an inch to several inches in thickness and is not very distinct except where defined by sand layers. Only a few layers of sand more than 1 inch thick and none more than 1 foot thick were observed.

The clay in the vicinity of this pit contains too few sand layers to be of importance as a source of ground water. This is indicated by the fact that, although the pit is close to Fresh Pond, very little ground water seeped into the pit.

The clay pit of the New England Brick Co. is abandoned and no longer affords exposures of the clay in place. The two pits of the A. H. Hews Co., located on the east side of Sherman Street a short distance east of the abandoned New England Brick Co. pit, are the only ones worked in the area in recent years. These pits are worked by dragline scaper, and, as a result, very little of the structure of the clay can be seen.

The abandoned clay pit on the north side of Concord Avenue 3,000 feet northwest of Fresh Pond is said to have been deep and to have yielded good quality brick clay. It is probable, therefore, that thick beds of sand and gravel were not abundant in this pit. The logs of boreholes in the lowland north of Fresh Pond show only a few layers of sand or gravel more than 1 to 2 feet thick below the surface layer of sand and gravel of outwash 4.

Shaler, Woodworth, and Marbut (1896, p. 990 and 995) observed folds in the Cambridge clay pits which they believed were caused by the last ice sheet overriding the clay. At the time of the writer's study these folds were not visible; only broad undulations of the stratification, such as could have been caused by deposition of the clay over a slightly uneven surface, and a few small folds were seen.

A fold 2 to 3 feet across was observed in the clay about 10 feet above the floor at the west side of the New England Brick Co. pit. This fold died out both upward and downward; it is reasonably certain that it was caused by local sliding of the clay and not by a readvance of the ice sheet over the clay. Horizontal or nearly horizontal beds were observed in the clay to within 3 feet of the top edge 
of the pit, where the stratification was obscured by weathering. No evidence of disturbance was found which could be attributed to overriding ice.

The writer believes that the folds in the clay are best explained as being due to (a) drag of grounded icebergs, (b) sliding of clay deposited in unstable positions on sloping surfaces, (c) impact of large boulders dropped into the clay from floating ice, and (d) slump caused by the melting of ice blocks against which the clay was deposited.

At present there is no certainty as to whether the clays of the Boston basin area, including those in the vicinity of Fresh Pond, are of marine or nonmarine origin. W. O. Crosby $(1903$, p. 83$)$ found no fossils in these clays, and, therefore, he believed that they were deposited in a fresh-water glacial lake which he called Lake Shawmut. To account for the formation of Lake Shawmut he assumed that a large mass of glacial ice existed to the east of the area in Boston Harbor and blocked the drainage of the area, thus causing the formation of the lake.

A notable feature of the clay, as exposed in the clay pits in Cambridge, is the absence of varves. The fact that the clay is not varved indicates strongly that it is of brackish-water or marine origin rather than fresh-water origin. Hörner (1929, p. 130) noted the absence of varves in the clay in Cambridge and suggested that the clay was deposited in an arm of the sea. Shaler, Woodworth, and Marbut $(1896$, p. 994) also believed the clays to be of marine origin. They wrote:

The estuarine or marine origin of the brick clays in the Boston basin has not been directly proved, but it is at least extremely probable. No marine fossils have been found in them, nor have they been traced continuously to a connection with clays carrying marine fossils. Their constitution shows that they were deposited in quiet water. Their positions show that they were laid down in estuaries which were open to the sea.

At the request of R. L. Nichols (written communication, 1942), A. S. Knox examined clay from the New England Brick Co. pit in Cambridge for microfossils. Two kinds of sponge spicules, some water-lily pollen, and pollen from trees and shrubs were found in the silt and fine sand layers in the clay. Nichols believes that the clay was deposited in an arm of the sea that was freshened at its landward end by the inflow of glacial streams.

Evidence has been presented for the existence of clays of at least three different ages in the area discussed in this report. The oldest clay known in the area was deposited before the readvance of the ice that formed the Fresh Pond moraine and was partly scraped up to form the moraine; next in age is the clay interbedded with outwash 2; the youngest is the clay that underlies the surface north of the Fresh 
Pond moraine, which has been worked extensively for brick and pottery clay. All these clays are probably of marine or brackish-water origin and represent deposition which took place each time the ice retreated from the Boston basin. The readvance of the ice stopped clay deposition in the area of the ice lobe, but it was resumed again as soon as the ice had melted sufficiently for the water body to reoccupy the lowland.

The deposition of the clay of the sixth event came to an end when the water body covering the lowlands of the Fresh Pond area was drained. If, as seems likely, the water body was a marine embayment, the draining of the area probably was caused by uplift of the land.

\section{SEVENTH: DEPOSTTION OF OUTWASH 4}

After the deposition of most of the clay of the sixth event, outwash 4 was deposited as a large alluvial fan southward over the clay. Outwash 4 extends from the south end of the Mystic Lakes to the area of artificial fill just north of Fresh Pond, and eastward around the northeast end of the Fresh Pond moraine, and beyond the mapped area (pl. 14).

The highest part of the fan is near the mouth of the valley of Mill Brook; although this geographic position suggests that the fan was deposited by a stream from that valley, it is more probable that most of the fan was deposited by the stream that flowed down the Mystic Lakes valley. The small areas of outwash 4 southwest of Spy Pond and around the west side of Fresh Pond were deposited by other, more local streams.

The fan shape and the absence of clay on the surface of outwash 4 indicate that the water body in which the clay of the sixth event was deposited was partly or wholly drained during or before the deposition of the fan. That the deposit is part of the glacial sequence is shown by the fact that it was formed while the ice block that covered the site of Spy Pond was still present, for, if the fan had been deposited after the ice block had melted, the depression occupied by the pond would have been filled.

Outwash 4 is composed mainly of sand and pebble-sized gravel. As far south as the southern end of Spy Pond the deposit consists of interbedded sand and pebble-sized gravel; farther south it consists mainly of sand. Borings east and southeast of Spy Pond penetrated a small amount of clay in the sand of this stage, which may have been deposited before the body of water that covered the area had drained completely.

The logs of boreholes show that in many places outwash 4 rests on clay within a fow feet of mean sea level. This relationship indicates that the clay deposit of the sixth event was built up to this level before 
outwash 4 was deposited over it. The variations in the altitude of the clay surface underlying the outwash may be due at least partly to such factors as the original variations in the surface of the clay, variations in compaction of the clay caused by the weight of the overlying sand and gravel, erosion of stream channels in the surface of the clay at the beginning of the deposition of outwash 4, and the melting of ice blocks buried in the clay.

The larger glacial streams that carried the sediment into the embayment north of the Fresh Pond moraine followed the valleys of Mill Brook and the Mystic Lakes. Where they entered the bay, sand and gravel probably were deposited while clay was being deposited farther south. Therefore, the northern part of the deposit of the sixth event may contain more sand and gravel than is present elsewhere and be difficult to distinguish from outwash 4 in the logs of the boreholes. For example, borehole 172, located 1,000 feet east of Spy Pond, on the southwest side of Massachusetts Avenue opposite Bates Road, is reported to have penetrated fine yellow sand containing some clay and gravel to a depth of 51.5 feet. Below that zone a bed of soft plastic blue clay 3 feet thick and containing some very fine sand was penetrated to the bottom of the hole. From these borehole data it is impossible to locate the contact between the clay of the sixth event and the sand and gravel of the seventh event. The logs of boreholes 1,517, $1,655,1,650$, and 1,647 (pl. 17) show that, along the railroad southeast of the Lower Mystic Lake, outwash 4 ranges from 18 to 40 feet in thickness and in most places rests on clay or sand and clay from a few feet above to a few feet below mean sea level. A borehole 2,500 feet southeast of Spy Pond on the southwest side of Massachusetts Avenue and about 20 feet northwest of Varnum Street shows outwash 4 at that locality to be 25 feet thick and to rest on clay approximately at mean sea level. Boreholes 371, 386, and 372 (pl. 15) show that, northeast of the New England Brick Co. clay pit, outwash 4 is 10 to 15 feet thick and rests on sand and clay at altitudes ranging from 5 to 11 feet above mean sea level. In general, the thickness of outwash 4 ranges from 30 to 40 feet at its northern end to a few inches at its margin north of Fresh Pond.

The valley of Alewife Brook crosses outwash 4 northeast of Fresh Pond and separates the part of outwash 4 southeast of the brook from the main part of the outwash fan. This valley, which presumably was eroded after the outwash had been deposited, interrupts the surface continuity of the fan to such an extent that it is difficult to determine if all the sand and gravel southeast of the valley belongs to outwash 4 . A small ridge of sand and pebble-sized gravel on the northeast side of Massachusetts Avenue at the east edge of the area mapped (pl. 14) intercepts the 30-foot contour and may be too high to be a part of the fan; it may, therefore, be an older deposit partly buried by the fan. 


\section{FIGHTH: FROSION OF VALLEYS IN THE OUTWASH}

The Aberjona River, Horn Pond Brook, Mill Brook, and the MysticRiver all flow in valleys eroded by late glacial streams in outwash deposits of the latest glacial stage. Much of outwash 4 may havebeen derived from the erosion of the Aberjona River and Horn Pond Brook valleys. Apparently at the time of this erosion ice blocks remained in the Mystic Lakes kettle holes-otherwise these basins should: have been filled with sand and gravel. The small segments of low terraces around the Mystic Lakes probably were formed at this time.

That some small ice blocks were in the Aberjona River valley either. before or during the erosion of the valley in the outwash is suggested. by the fact that the valley is not of uniform width. The sides of the valley are terraced in places, but these terrace remnants are too complicated for separate mapping in this survey. Apparently the erosion of this valley was controlled by the melting of the ice blocks that wereat the sites of the Mystic Lakes. These blocks seem to have acted as. temporary base levels, and, as the ice blocks melted, the valley was. eroded deeper. The valley of the Mystic River was eroded in outwash. 4 after most of this outwash had been deposited and, therefore, probably began to form later than the valley eroded in outwash 3 by the Aberjona River.

\section{NINTH: MELTING OF ICE BLOCKS}

After the deposition of glacial outwash ceased, the last remnants of ice blocks that occupied the basins of the present ponds melted away. They lasted longer than the ice in adjacent areas either because the ice was thicker or because they were protected from rapid melting by covers of sediment.

The amount of horizontal shrinkage of the ice blocks from the time of deposition of the early outwash to the end of deposition of outwash 4 is indicated in places by sand flats around the ice-block holes. For example, the shrinkage of the Fresh Pond ice block between the deposition of outwash 2 and outwash 4 is represented by the lowland bordering the west side of Fresh Pond. Similar flats, probably formed after the deposition of outwash 3, border the Mystic Lakes and Wedge Pond.

TENTH: FORMATION OF POSTGLACIAL STREAM AND SWAMP DEPOSITS

Since the last of the glacial-ice masses in the Fresh Pond area melted away, some clay, silt, sand, gravel, and peat have been deposited in the streams, ponds, and marshes. For the most part these deposits are small and are concealed under the ponds and marshes; only those on the floors of the stream valleys are shown on the map (pl. 14).

Borings made in 1904 for the Metropolitan Park Commission (Winslow and Underwood, 1904; also plan and sections of borings in the. 
Alewife Brook marshes in Freeman, 1904) penetrated three deep deposits of peat between Fresh Pond and Spy Pond. One of these deposits borders outwash 2 northeast of the Cambridge Sanatorium and extends north to the Boston and Maine Railroad. This lenticular deposit has a diameter of about 1,200 feet and a maximum thickness of about 40 feet. Directly north of it, beneath the marsh area between the railroad and the Concord Turnpike, is another peat deposit that is said to have a maximum thickness of 60 feet. The third peat deposit is about 40 feet thick and underlies Spy Pond, which is about 12 feet deep. These thick peat deposits were formed in kettle holes produced by the melting of ice blocks buried in the clay and outwash deposits.

\section{SUMMARY OF GLACIAL DEPOSITS IN THE FRESH POND AREA}

Many holes have been drilled in the vicinity of Fresh Pond to determine the character of the deposits that underlie the area. The logs of the holes differ so much that it is usually difficult or impossible to correlate layers of clay, sand, gravel, and other material from one hole to another.

By interpreting the geologic history of the deposits as worked out from a study of the surface geology and the borehole records, it is possible to predict in a general way the distribution and character of the clay, sand, and gravel deposits both horizontally and vertically and to interpret the borehole logs more accurately. The distribution of the clay and the sand and gravel deposits in the Fresh Pond area thus inferred is outlined below as far as present knowledge permits.

Because clay and clayey till are too impermeable to permit appreciable movement of ground water, their distribution is of much importance in tracing the movement of ground water in the Fresh Pond area. The southeastern half of Fresh Pond is bordered chiefly by clayey till and clay with only small amounts of interbedded sand and gravel. These deposits seem to extend to a depth of 50 to 80 feet, perhaps even deeper. The clayey till probably passes under Fresh Pond, as suggested by section $Q-Q^{\prime}$ on plate 16 , but it may be thinner and less continuous than is indicated by the section. The water level in a test well that is 43 feet deep and located 1,300 feet south of the southwest corner of Fresh Pond is reported by C. M. Roberts (oral communication, 1946) to have fluctuated with the change in the level of Fresh Pond, thus indicating a ground-water connection between them. This connection, however, is probably through the sand and gravel of outwash 2 on the west side of Fresh Pond rather than through the till of the moraine at the south side of Fresh Pond.

The northwestern half of Fresh Pond is bordered by the sand and gravel of outwash 2 and outwash 4 . These deposits apparently pro- 
vide most of the ground water that may be drawn into Fresh Pond. The surface distribution of these deposits is shown on plate 14; their vertical extent at the north side of Fresh Pond is shown in section $R-R^{\prime}$, plate 16. The log of borehole 14 (pl. 15) shows that outwash. 2 west of the northwest corner of Fresh Pond consists of sand and gravel with a small amount of clay. Two deep boreholes in outwash 2 at the City Home on the north side of Fresh Pond reveal that the deposit there consists chiefly of sand with traces of clay. The upperpart of borehole 796 ( $\mathrm{pl} .14$ ) penetrated 14 feet of clay, but this is the younger clay of the sixth event which overlaps the edge of outwash 2.

Outwash 4 on the northwest side of Fresh Pond was deposited between outwash 2 and the edge of the shrinking ice block. The logs of 2 deep boreholes in outwash 4 on the west side of Fresh Pond show sand and gravel with a small amount of clay to depths of 15 and 25 feet, respectively; this zone is underlain by clay containinga small amount of sand and gravel that extends to bedrock, which was reached at depths of 88 and 111 feet, respectively. On the north. side of the pond, boreholes show that outwash 4 consists of sand and gravel with some interbedded clay, and that it is covered in places: by fill and peat.

The clay that underlies the west side of Fresh Pond at depths of 15 to 25 feet probably is a barrier to the movement of ground waterinto Fresh Pond from the west. Even the small pond in outwash 4 at the west side of Fresh Pond is separated from Fresh Pond by impermeable material, for the pond was not lowered when the level of Fresh Pond was down 15 to 20 feet.

Outwash 2 is separated from the sand and gravel deposits of outwash 3 by the clay deposits of the sixth event along the line of the railroad south of Little Pond (pl. 16, sections $Q-Q^{\prime}$ and $S-S^{\prime}$ ). North of Fresh Pond, however, the clay is interrupted by thick deposits of peat, according to the records of many borings made in the marshes north of Fresh Pond by William T. Pierce in 1904 (Freeman, 1904, plate showing plan and sections of borings in the Alewife Brook marshes). The peat deposits fill kettle holes left by the melting of ice blocks. These deposits range in diameter from about 300 to 1,500 feet, and have a maximum thickness of about 60 feet. The peat is: underlain in many places by sand, which in turn is underlain by clay.

If there is any significant southward movement of ground water within 60 feet of the surface, along the buried valley to Fresh Pond, it is probably through the thick peat deposits and their associated sands in a zone 1,000 to 2,000 feet wide. Elsewhere north of Fresh Pond, between the areas underlain by outwash 2 and outwash 3, the clay of the sixth event forms a barrier across the buried valley, and, although there may be some flowage of ground water through. 
a few intercalated sand beds, the quantity of water is probably small. The water levels in test wells within a mile north of Fresh Pond are reported by C. M. Roberts (oral communication, 1946) to have fluctuated with the changes in level of the pond. This indicates that the deposits are sufficiently permeable for ground water to flow through this area to Fresh Pond.

Although sand and gravel are present at the surface in this area, the deposits are not continuous to Fresh Pond. The sand and gravel deposits north of the Boston and Maine Railroad-between Spy Pond and Fresh Pond-are separated or nearly separated from those to the south by clay deposits about 50 feet thick. The extensive sand and gravel deposits of outwash 4 southeast, east, and northeast of Spy Pond are relatively thin deposits overlying clay; they pinch out before they reach Fresh Pond and hence are not a source of ground water for the pond.

The New England Brick Co.'s clay pit illustrates the relative imperviousness of the clays northeast of Fresh Pond. Although the clay pit is 1,500 feet in diameter and about 50 feet deep, it has not lowered the water level in the marshes adjacent to it on the northwest, nor is there much seepage into it from Fresh Pond.

The marshes to the north of Fresh Pond are said to be drained when the level of Fresh Pond is lowered appreciably. Winslow and Underwood (1904, p. 101) state that:

In 1879, when the Cambridge Water Board had borings made, small wells being driven all over the territory between the meadows and Fresh Pond, it is stated that a rapid underflow was found setting from the marshes toward the water :supply; and in their report of that year the commissioners advise that these meadows should be kept clean, to avoid contamination of the Fresh Pond water. We understand that certain investigations carried on last November also led to the conclusion that when Fresh Pond was drawn low by pumping, a portion of the marsh drained toward it through the substrata.

When the level of Fresh Pond was lowered in the fall of 1944, the small pond at the north side of Fresh Pond was drained, but the writer did not observe any change in the water level in the remnants of the marshes north of Concord Avenue. The large amount of fill that has been dumped over the marshes may have compressed the underlying peat considerably and reduced its permeability so that ground water flows through it less freely than formerly.

As indicated in section $S-S^{\prime}$ on plate 16, Fresh Pond is probably underlain by clayey till; therefore it is doubtful that much ground water enters Fresh Pond from below. Very little is known about the character of the deposits in the inner gorge of the buried valley at depths greater than 80 feet below mean sea level. The only boreholes known to the writer which penetrate the inner gorge are Nos. 55, 56, 57,58 , and 385 (pl. 15). The logs of these borings show layers of clay, sand, gravel, and bouldery material complexly interbedded. The ground water in these deposits is probably stagnant. 


\section{SELECTED BIBLIOGRAPHY}

Brown, R. M., 1902, The clays of the Boston Basin: Am. Jour. Sci., 4th ser., v. 14, p. $445-450$.

Clapp, F. G., 1901, Geological history of the Charles River in Massachusetts: Tech. Quart., จ. 14, p. 171-201, p. 255-269.

-_ 1902, Geological history of the Charles River in Massachusetts: Am. Geologist, v. 29, p. 218-233.

Crosby, I. B., 1923, The earthquake risk in Boston: Boston Soc. Civil Engineers Jour., v. 10, p. 421-430.

1934, Evidence from drumlins concerning the glacial history of Boston Basin : Geol. Soc. America Bull., v. 45, p. 135-158.

1937, Ground-water conditions of parts of Middlesex, Worcester, and Norfolk Counties in the buried valleys of the preglacial Merrimack, Sudbury, and Charles Rivers: Commonwealth of Massachusetts Dept. Public Health, Public Doc. 34, Ann. Rept. year ending Nov. 30, 1937, p. 219-224.

1939, Ground water in the pre-glacial buried valleys of Massachusetts: New England Water Works Assoc. Jour., v. 53, p. 372-383.

- 1945, Glacial erosion and the buried Wyoming valley of Pennsylvania: Geol. Soc. of America Bull., v. 56, p. 389-400.

Crosby, W. O., 1890, Composition of the till or boulder clay: Boston Soc. Nat. History Proc., v. 25, p. 115-140.

—_ 1896, Glacial lakes of the Boston Basin [abs.] : Am. Geologist, v. 17, p. 128-130.

- 1899, Geological history of the Nashua Valley during the Tertiary and Quaternary periods: Tech. Quart., v. 12, p. 288-324.

-__ 1903, A study of the geology of the Charles River estuary and Boston Harbor with special reference to the building of the proposed dam across the tidal portion of the river: Tech. Quart., v. 16, p. 64-92.

Freeman, J. R., 1904, Improvement of the upper Mystic River and Alewife Brook by means of tide gates and large drainage channels: Boston Metropolitan Park Comm. Rept., Sept. 21, 1904.

Hörner, N. G., 1929, Late glacial marine limit in Massachusetts : Am. Jour. Sci., 5th ser., v. 17, p. 123-145.

Johnson, Frederick, and others, 1942, The Boylston Street Fishweir: Phillips Acad., Andover, Mass., Robert $\mathbf{S}$. Peabody Foundation for Archaeology Papers, v. 2, 212 p.

LaForge, Laurence, 1932, Geology of the Boston area, Massachusetts: U. S. Geol. Survey Bull. 839, 105 p.

Lane, A. O., 1928, Till on overthrust gravels : Geol. Mag., v. 65, p. 8-11.

Shaler, N. S., Woodworth, J. B., and Marbut, C. F., 1896, Glacial brick clays of Rhode Island and southeastern Massachusetts: U. S. Geol. Survey 17th Ann. Rept., pt. 1, p. 957-1004.

S.himer, H. W., 1918, Postglacial history of Boston: Am. Acad. Arts Sci. Proc., v. 53, p. 441-463.

Winslow, O. E. A., and Underwood, W. L., 1904, Report on the sanitary problems relating to the Fresh Pond marshes and Alewife Brook, App. 2 of Freeman, J. R., Improvement of the Upper Mystic River and Alewife Brook by means of tide gates and large drainage channels: Boston Metropolitan Park Comm. Rept., Sept. 21, 1904.

Woodworth, J. B., 1897, Some glacial wash plains of southern New England: Essex Inst. Bull., v. 29, p. 71-119. 



\section{INDEX}

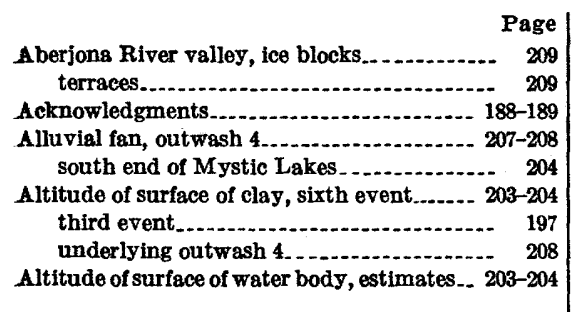

Bedrock surface in buried valleys, profile sections..................... 192; pl. 14 seismic traverses. 191,193

Belmont, buried tributary valley.

Boston basin, buried valley cut in sedimentary rock.

kame terrace.

195

retreat of fce

Boston basin lowland, composition of clay... 203, 205,206

Borehole logs $188-190,191$, $193,194,197,203,204,205,207,208,209$ $210,211,212 ;$ pls. 14, 15, 17.

Charles River, buried valley of preglacial..... 190 $192,193,195 ;$ pl. 14 seismic traverses along north side .. 192, 193-194

Clay, age. 206-207 origin. . . 206, 207

Clay and clayey till deposits, distribution in Fresh Pond area......... 210,212; pl. 16

Clay deposits, distribution in Fresh Pond area.

211,212

Clay of sixth event, age

206-207 composition

203,205

deposition $202,205,206-207,208$

folds 205-206 thickness $205-206$
$-\quad 203$

Clay of third event, deposition._._. 196-197; pl. 16 Consolidated Chemical Industries Co., wells.- 191

Crosby, I. B., quoted. 190,203

Crosby, W. O., quoted. 200

Extent and location of buried valleys $189-190$

Faults, thrust

Fells Upland, buried valley

Fieldwork

olds, Cambridge clay pits................ 205

New England Brick Co. clay pit........ 205 strata of outwash 2 . . . . . . 201-202

Fresh Pond, gravel ridge.............. 204 ice block occupied basin.... 198, 204, 205, 209, 211

Fresh Pond area, distribution of clay and sand and gravel deposits............ 210-212 ground water.................... 188, 205, 210-212 summary of glacial deposits............ 210-212 water levels in test holes
Fresh Pond buried valley

Page

189-190.

$193-194,196,197,199 ;$ p1. 14 rock terrace..................... 189, 191; pl. 15 tributary baried valleys................. 194-195

Fresh Pond moraine, composition. ....... 198-200 formation........... 197-199, 200, 203

Gap, southwest of Belmont town hall....... 202 Geologic cross sections . . . . .

Glacial deposits, formation. ................ 195

Fresh Pond ares, summary ............ 210-212

history . . . .

Glacial streams.............. 208, 209

Gorge, inner, of buried valley............. 189, 212

Ground moraine, deposition . . . ... 195-196; pl. 15

Ground water, Fresh Pond area. ... 188, 205, 210-212

Hews Co., A. H. clay pits . .

History of glacial deposits . . . . . . .

Horn Pond, buried tributary valley ......... 194

Horn Pond Brook, buried tributary valley ... 194

Ice, direction of movement. ............. 199

Ice-block holes, sand flats................... 209

Ice blocks. . . . . . ................... 198, 204, 205, 209, 211 melting _..... 195, 196, 202, 206, 207, 208, 209, 211

Ice sheet, glacial deposits formed by ... 195-196, 200

Kame terraces, outwash 3................ 202

Kames, age

composition. . .

Kettle holes . . ................. 196, 202, 209, 210, 211

Knox, A. S., identification of microfossils.... 206

LaForge, Laurence, quoted................. 190

Lake Shawmut, fresh-water glacial lake....... 206

Little Pond, ice block occupied basin........ 205

Marbut, C. F., quoted. .............. 203, 206

Merrimack River valley, preglacial......... 188, 190

Microfossils in clay.......................... 206

Mill Brook, buried tributary valley .......... 194

Mishawum Lake, buried tributary valley.... 194

Mystic Lakes, ice blocks occupied basins .. 205, 209

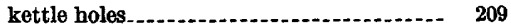

terraces.

Mystic Lakes buried valley........... 190, 191, 192

Mystic River, buried tributary valley ........ 194

Neponset River, buried valley of preglacial... $\quad 190$

New England Brick Co., clay pit............ 200,

$208,204,205,206,208,212$

Outwash 1, deposition. 196

Outwash 2, composition. ................ 200-201

distribution of sand and gravel $\ldots 210-211$; pl. 14

folds in strata. . .

formation......... 200 


\begin{tabular}{|c|c|}
\hline Page & Page \\
\hline utwash 3, composition & Seismic traverses, along north side of Charles \\
\hline sition. & River \\
\hline 209 & between Upper and Lower Mystic Lakes_ 191- \\
\hline 212 & 192 \\
\hline $204,207-208,212$ & east side of Spy Pond, Arlington........ 191-192 \\
\hline lerlying ......... 208 & Shaler, N.S., quoted...... \\
\hline $\begin{array}{r}\text { composition } \\
\text { deposition. } \\
\text { distribution of sand and gravel }-204,211 ; \text { pl. } 14 \\
211,212 ; \text { pl. } 14\end{array}$ & $\begin{array}{l}\text { Spy Pond, ice block occupied basin.... 205, 207, } 210 \\
\text { peat deposit... } \\
\text { seismic traverses along east side, Arling- } \\
\text { ton }\end{array}$ \\
\hline thickness. & 210, 212; pl. 16 . \\
\hline$n$ and swamp deposits forma- & Underwood, W. L., quoted \\
\hline urpose of report 188 & $\begin{array}{l}\text { alleys, buried } \\
\text { erosion of, }\end{array}$ \\
\hline $\begin{array}{r}\text { ock terrace in Fresh Pond buried valley.... } 189, \\
191 ; \text { pl. } 15\end{array}$ & area..- \\
\hline $\begin{array}{l}\text { ctions, profile, bedrock } \\
\text { valleys }\end{array}$ & Winslow, C. E. A., quoted \\
\hline
\end{tabular}

